ZOOLOGIA 31 (4): 389-392, August, 2014

http://dx.doi.org/10.1590/S1984-46702014000400010

\title{
On the sharpshooter Versigonalia (Hemiptera: Cicadellidae: Cicadellini): Versigonalia lentiginosa nom. nov., redescription of $V$. vermiculata comb. nov., and key to species of the genus
}

\author{
Beatriz M. Camisão ${ }^{1,2} \&$ Daniela M. Takiya ${ }^{1}$
}

\begin{abstract}
1 Programa de Pós-graduação em Biodiversidade e Biologia Evolutiva, Laboratório de Entomologia, Departamento de Zoologia, Instituto de Biologia, Universidade Federal do Rio de Janeiro. Caixa Postal 68044, 21941-971 Rio de Janeiro, RJ, Brazil.

${ }^{2}$ Corresponding author: biacamisao@gmail.com
\end{abstract}

\begin{abstract}
Syntypes of Tettigonia vermiculata Signoret, 1855 were studied and redescribed, including the first description and illustration of the male and female genitalia of this species. Based on this study, this Brazilian species, previously placed in Molomea (Proconiini), is herein transferred to Versigonalia (Cicadellini). This transfer resulted in a secondary homonymy and its junior homonym from Argentina, Versigonalia vermiculata Young, 1977 is considered invalid. Thus, we propose a new name, $V$. lentiginosa nom. nov., for the latter. A taxonomic key to all three species of Versigonalia is also given.
\end{abstract}

KEY WORDS. Cicadellinae; leafhoppers; new combination; taxonomy.

Cicadellinae includes ca $9 \%$ of the diversity of Cicadellidae and is currently divided into two tribes, Cicadellini and Proconiini (Young 1968, 1977). Although members of Cicadellini are distributed in all major zoogeographical areas, by far the majority of its diversity is found in the New World, from where approximately 175 genera and 1,200 species have been described (see Cavichioli \& TaKiYa 2012).

The original description of the Brazilian species Tettigonia vermiculata Signoret, 1855 is very short, ambiguous, and does not include illustrations, making it impossible to identify this species. In fact, because the genital structures are not described in it, the original description alone does not allow the species to be properly placed in any of the current genera - the majority of which were described or redescribed in Young's (1968, $1977,1986)$ taxonomic revisions of the Cicadellinae. In an attempt to place all sharpshooter species described until 1955 into available genera, Metcalf (1965) placed T. vermiculata in Amblyscarta Stål, 1869 (Cicadellini), but failed to give any justification for it. Later, Young (1968) implicitly transferred it to Molomea China, 1927 (Proconiini) and suggested that it could be a synonym of Molomea consolida Schröder, 1959. Most likely, he based his conclusion on specimens identified by C. Berg as T. vermiculata, and which were actually conspecific with $M$. consolida. Young (1968) did not have access to type-specimens of $T$. vermiculata, thus he did not illustrate its genitalia.

After studying male and female syntypes of $T$. vermiculata deposited at Museum für Naturkunde (ZMHB), Berlin, we have concluded that the correct placement of this species is in Versigonalia Young, 1977. Versigonalia currently includes the typespecies, V. ruficauda (Walker, 1851), and V. vermiculata Young, 1977. The transfer of T. vermiculata Signoret, 1855 to Versigonalia, however, results in Versigonalia vermiculata Young, 1977 becoming a secondary junior homonym and thus invalid. Therefore, given that it has no available synonyms, a new substitute name is proposed for this species (articles 53.3 and 60.1 in ICZN 1999). A redescription of the senior homonym based on the type-specimens and a key to species of Versigonalia are provided.

Additional specimens studied are deposited at Coleção Entomológica Prof. José Alfredo Pinheiro Dutra, Departamento de Zoologia, Universidade Federal do Rio de Janeiro, Rio de Janeiro (DZRJ); Illinois Natural History Survey, University of Illinois, Champaign (INHS); and Museo de La Plata, Universidad Nacional de La Plata, La Plata (MLPA). A stereoscopic microscope with camera lucida was used for observation and illustration of the specimens. Techniques for preparation of genital structures were described by Oman (1949). Terminology follows Young (1968, 1977), Mejdalani (1998), and Zahniser \& Dietrich (2008).

\section{TAXONOMY}

\section{Versigonalia vermiculata (Signoret, 1855) comb. nov.}

Figs 1-11

Tettigonia vermiculata Signoret. Signoret, 1855: 785 (sp. nov.). Amblyscarta vermiculata (Signoret). Metcalf, 1965: 231 (comb. nov.). Molomea vermiculata (Signoret). Young, 1968: 242 (implicit comb. nov.).

Type-locality. Brazil [without specific locality].

External morphology. Head with median length between 0.5 to 0.6 times interocular width and between 0.3 to 0.4 times transocular width; ocelli located slightly behind line between 

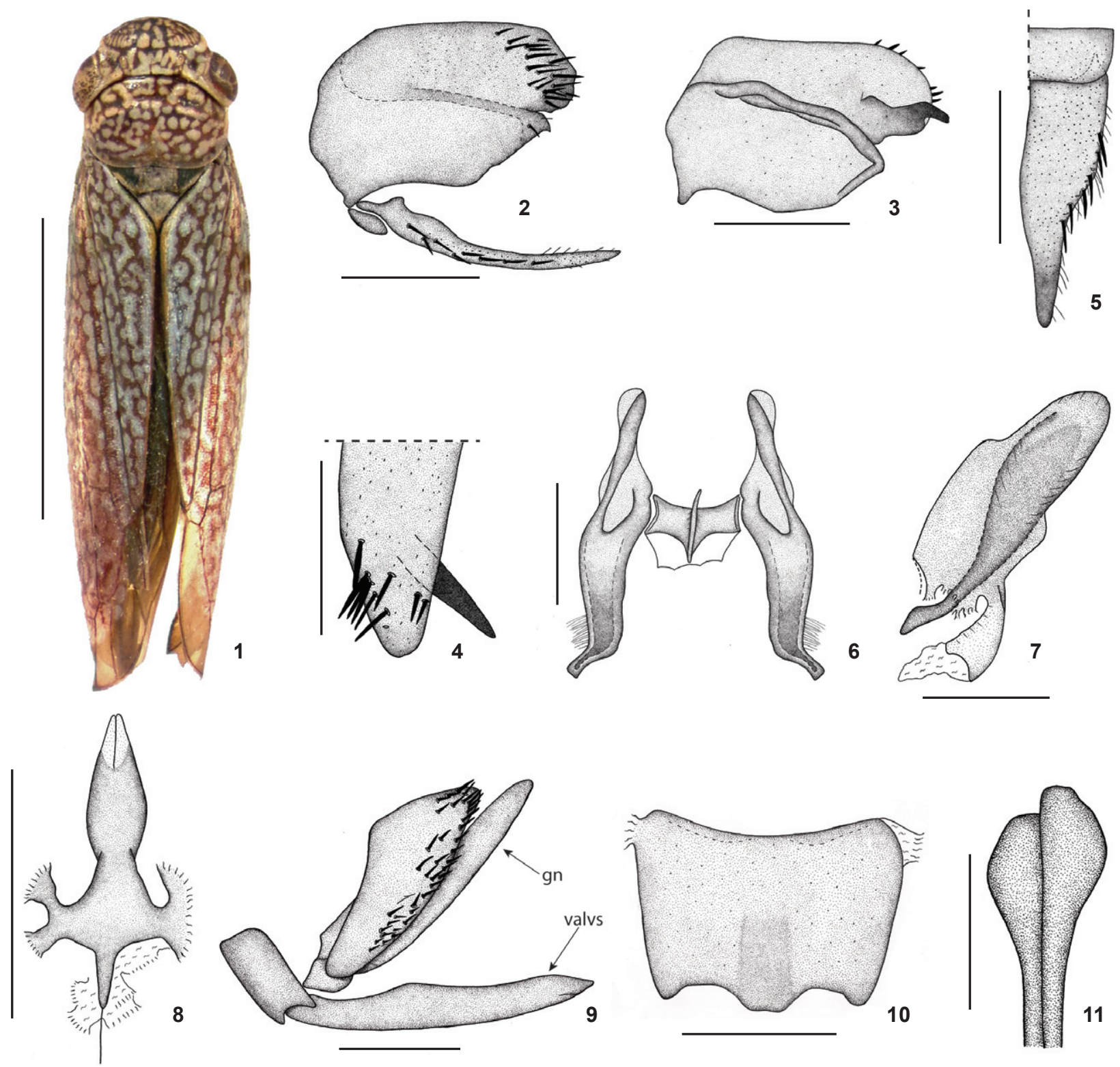

Figures 1-11. Versigonalia vermiculata, syntypes: $(1,9-11)$ female syntype; $(2-8)$ male syntype. (1) Dorsal habitus, photo from WiLson et al. 2009; (2) pygofer, valve, and subgenital plates, outer lateral view; (3) pygofer lobe, internal lateral view; (4) pygofer, apex, dorsal view; (5) subgenital plate and valve, ventral view; (6) styles and connective, dorsal view; (7) aedeagus, lateral view; (8) aedeagus, caudal view; (9) pygofer, sternite VII, and gonoplac, lateral view; (10) abdominal sternite VII, ventral view; (11) bases of valvulae I, ventral view. (gn) Gonoplac; (valvs) valvulae I and II. Scale bars: 1, 4, 6, 7, $11=0.5 \mathrm{~mm}, 2,3,5,8,10=1.0 \mathrm{~mm}, 9=2.0 \mathrm{~mm}$.

anterior eye angles. Pronotum width less than transocular width; posterior margin slightly concave. Forewings with membrane including first apical cell entirely and apex of the remaining ones; with five apical cells. Other characters as in Versigonalia description by Young (1977).

Coloration. Crown, pronotum, mesonotum, and forewings pale white to dull yellow (Fig. 1); with brown reticulate lines. Mesonotum with pair of dark triangular maculae near basolateral angles.

Male genitalia. Pygofer lobes with process arising from internal surface anteapically (Figs 2-4); macrosetae distributed at apical third; apex truncate. Subgenital plates extending posteriorly beyond pygofer apex; with uniseriate macrosetae and microsetae on lateral margin (Fig. 5). Connective Y-shaped (Fig. 
6). Styles (Fig. 6) extending beyond apex of connective, with apex narrowed and truncate, directed ventrally. Aedeagus (Figs 7-8) in lateral view with shaft broad, median constriction and apex round; with basal constriction in caudal view, becoming broader on midlength. Paraphysis absent.

Female terminalia. Abdominal sternite VII (Figs 9-10) with width greater than length; posterior margin with broad, median truncate projection, extending posteriorly slightly beyond lateral margins. Internal abdominal sternite VIII membranous with pair of lateral sclerotized regions. Pygofer (Fig. 9) with apex narrowly round. Valvifer I longer than wider; posterior margin slightly concave. Valvulae I with bases (Fig. 11), in ventral view, round; apex acute. Valvulae II with continuous subtriangular teeth on apical half of dorsal margin; teeth with denticles on anterior margin.

Material examined. Syntypes, 1 male, 1 female. 1 male, "Vermiculata Sign.", "syntype | Tettigonia | vermiculata | Signoret, 1855", "Bras. v. Olf.", "6624" (ZMHB). Female, "25 | syntype", "Brasil | V. Alfers | n. 6624", "Zool. Mus. Berlin", "Photographed by NMGW | Entom. | Image no. E003165", "Photographed by NMGW | Entom. | Image no. E003166" (ZMHB).

Remarks. Tettigonia vermiculata Signoret, 1855 is placed in Versigonalia Young, 1977 (Cicadellini) based on the following set of characteristics: 1) male pygofer with pair of internal anteapical processes (Figs 2-4); 2) long subgenital plates, extended posteriorly to apex of pygofer (Fig. 2); 3) styles with apex narrow, without conspicuous preapical lobe (Fig. 6); and 4) aedeagus with shaft broad and bisinuate in lateral view, with apex rounded (Fig. 7). Furthermore, this species shares with other Versigonalia species the southern South American distribution and dorsal habitus color pattern (Fig. 1) consisting of darker (reddish-brown to black) vermiculate lines over a yellow crown, anterior portion of pronotum, and mesonotum, and bluish- to yellowish-green (pale white in types of $V$. vermiculata, possibly discolored) posterior portion of pronotum and forewings. This vermiculate color pattern is not exclusive of Versigonalia and can also be found in some species of Macugonalia Young, 1977, but these genera can be easily separated by characters of the male and female terminalia.

Versigonalia vermiculata can be easily distinguished from the other two valid species of the genus by the following features: 1) styles with apex narrow and truncate in dorsal view (Fig. 6); 2) aedeagus in lateral view with apical half of shaft narrowed and apex rounded (Fig. 7), with basal constriction in caudal view (Fig. 8); and 3) female abdominal sternite VII with posterior margin with median projection truncate, extending posteriorly slightly beyond lateral margins (Fig. 10). Additionally, the single male syntype of $V$. vermiculata was found dissected prior to this study and apparently did not have any sclerite associated with the apex of the connective or the base of the aedeagus, which can be interpreted as homologous with the paraphysis present in other Versigonalia species. However, these genital structures were not well preserved and some of the membranous parts, such as the limits of the aedeagus, were dissolving, possibly due to continued $\mathrm{KOH}$ reaction in this very old material. Therefore, we cannot be certain that it did not have an inconspicuous paraphysis, as $V$. lentiginosa nom. nov.

\section{Versigonalia lentiginosa Camisão \& Takiya nom. nov.}

Versigonalia vermiculata Young, 1977: 1091 [preoc., junior homonym of Versigonalia vermiculata (Signoret, 1855)].

Type-locality. Loreto, Misiones, Argentina (Young 1977). Etymology. The new replacement name derives from the Latin adjective "lentiginosus", meaning spotted or freckled.

Comparative material examined. Argentina, Entre Ríos: Parque Nacional El Palmar, road to Mirador Arroyo El Palmar, $31^{\circ} 52^{\prime} 28^{\prime \prime} \mathrm{S} 058^{\circ} 13^{\prime} 57^{\prime \prime} \mathrm{W}, 30 \mathrm{~m}, 1$ male and 1 female, 16.II.2014, sweep, C.C. Gonçalves leg. (DZRJ); Parque Nacional El Palmar, Mirador Los Loros, near Arroyo Los Loros, 31 $51^{\circ} 41^{\prime \prime} \mathrm{S}$ $058^{\circ} 13^{\prime} 44^{\prime \prime} \mathrm{W}, 24$ m, 1 female, 15.II.2014, sweep, B.M. Camisão

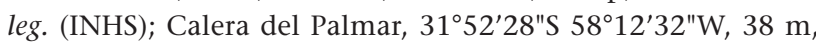
14.II.2014, sweep, 3 females, D.M. Takiya, C. Gonçalves \& B.M. Camisão leg. (MLPA).

Remarks. This species can be distinguished from the other two Versigonalia species by the following combination of characters: 1) mesonotum yellow with two pairs of triangular black maculae on the anterior margin; 2) apex of pygofer subangulate; 3) paraphysis inconspicuous, occurring as a small plate at the apex of connective; 4) female abdominal sternite VII with posterior margin almost rectilinear.

\section{Taxonomic key to species of Versigonalia Young, 1977}

1. Pronotum with posterior margin convex; male with connective U-shaped, paraphysis conspicuous, appearing as a ventral aedeagus process (Brazil) .............. V. ruficauda (Walker)

$1^{\prime}$. Pronotum with posterior margin slightly concave; male with connective Y-shaped, paraphysis inconspicuous ............ 2

2. Mesonotum yellow with two pairs of black maculae near anterior margin; male with apices of styles narrowly rounded; female with posterior margin of abdominal sternite VII almost straight (Argentina)

V. lentiginosa Camisão \& Takiya nom. nov.

2 '. Mesonotum dull yellow with single pair of black triangular maculae near anterior margin; male with apices of styles truncate; female with posterior margin of abdominal sternite VII mesally produced posteriorly as broad truncate projection (Brazil) ... V. vermiculata (Signoret) comb. nov.

Additional remarks. Given the redescription of $V$. vermiculata, we provide characters to separate the three valid species currently included in Versigonalia. However, we feel that it is important to point out that some characters used for distinguishing these species can be quite variable between specimens identified as $V$. ruficauda. Versigonalia ruficauda is one of 
the most common sharpshooter species in the Atlantic Forest of Rio de Janeiro and São Paulo states and intraspecific variation is present in the size, coloration, and morphology of the male and female terminalia (MEJDALANi 1998). More specifically, the length of processes of the male pygofer, the degree of sclerotization of the ventral process of the aedeagus (= paraphysis), and the degree of concavity of the posterior margin of the female abdominal sternite VII can vary greatly among individuals, overlapping with features of the other known species. Further detailed morphological studies, including a large number of specimens allied with molecular data may help delimit the extent of intraspecific variability and establish more reliable diagnoses for these species.

\section{ACKNOWLEDGMENTS}

The authors would like to thank J. Deckert and R. Mühlethaler (ZMHB) for their help during the visit of BMC to the Museum für Naturkunde, Berlin. Field work in Argentina was made possible by the efforts of M.I. Catalano (Universidad Nacional del Noroeste de la Provincia de Buenos Aires, DCM 451) together with the Administración de Parques Nacionales. We are greatly indebted to G. Mejdalani (Museu Nacional, Universidade Federal do Rio de Janeiro) for his opinions on the matter of $V$. ruficauda morphological variability and comments on a preliminary version of this manuscript. Fellowship for BMC during her M.Sc. studies was provided by a Conselho Nacional de Desenvolvimento Científico e Tecnológico (CNPq/ PROTAX proc. 562.303/2010-3) grant to DMT.

\section{LITERATURE CITED}

Cavichioli, R.R. \& D.M. Takiya. 2012. Four species of the new Amazonian sharpshooter Daedaloscarta gen. nov. (Insecta: Hemiptera: Cicadellidae). Zoologia 29 (6): 589-597. doi: 10.1590/S1984-46702012000600010

ICZN. 1999. International Code of Zoological Nomenclature.
London, The International Trust for Zoological Nomenclature, $4^{\text {th }}$ ed., 306p.

Mejdalani, G. 1998. Morfologia externa dos Cicadellinae (Homoptera, Cicadellidae): comparação entre Versigonalia ruficauda (Walker) (Cicadellini) e Tretogonia cribata Melichar (Proconiini), com notas sobre outras espécies e análise da terminologia. Revista Brasileira de Zoologia 15 (2): 451544. doi: 10.1590/S0101-81751998000200015

Metcalf, Z.P. 1965. General catalogue of the Homoptera. Fascicle VI. Cicadelloidea. Part 1.Tettigellidae. Washington, D.C., United States Department of Agriculture, Agriculture Research Service, 730p.

Oman, P.W. 1949. The Nearctic leafhoppers (Homoptera: Cicadellidae). A generic classification and check list. Memoirs of the Entomological Society of Washington 3: 1-253.

Signoret, V. 1855. Revue iconographique des Tettigonides. Annales de la Société Entomologique de France 3: 507-528.

Wilson M.R.; J.A. Turner \& S.H. McKamey. 2009. Sharpshooter leafhoppers of the world (Hemiptera: Cicadellidae subfamily Cicadellinae). National Museum Wales. Available online at: http://naturalhistory.museumwales.ac.uk/ Sharpshooters. [Accessed: 07/XII/2013].

Young, D.A. 1968. Taxonomic study of the Cicadellinae (Homoptera: Cicadellidae), Part 1, Proconiini. Bulletin of the United States National Museum 261: 1-287.

Young, D.A. 1977. Taxonomic study of the Cicadellinae (Homoptera: Cicadellidae), Part 2, New World Cicadellini and the genus Cicadella. Technical Bulletin of the North Carolina Agricultural Experiment Station 239: 1-1135.

Young, D.A. 1986. Taxonomic study of the Cicadellinae, Part 3, Old World Cicadellini. Technical Bulletin of the North Carolina Agricultural Experiment Station 281: 1-639.

Zahniser, J.N. \& C.H. Dietrich. 2008. Phylogeny of the leafhopper subfamily Deltocephalinae (Insecta: Auchenorrhyncha: Cicadellidae) and related subfamilies based on morphology. Systematics and Biodiversity 6 (1): 1-24. doi: 10.1017/ S1477200007002617

Submitted: 02.V.2014; Accepted: 06.VII.2014.

Editorial responsibility: Gabriel L.F. Mejdalani

ZOOLOGIA 31 (4): 389-392, August, 2014 